\section{The public-private-people partnership (P4) for cultural heritage management purposes}
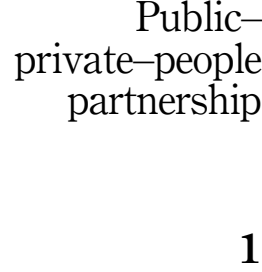

\author{
Department of Architecture, Built Environment and Construction Engineering, \\ Politecnico di Milano, Milan, Italy
}

\begin{abstract}
Purpose - In light of the difficulties the governments typically face in conserving and managing their rich public cultural heritage, which often lingers in a condition of neglect, this study aims to identify a set of additional tools capable of providing adequate financial resources as well as skills.

Design/methodology/approach - The general research methodology adopted is of a qualitative, rather than a quantitative, nature. In fact, the resulting considerations are mainly the consequence of a first broad theoretical examination, aimed at analyzing the different management models a public entity may adopt, and an applicable verification, aimed at describing some case histories selected by means of interviews.

Findings - The study develops a preliminary reflection on possible sector-specific models for public-built cultural heritage management that have not been well defined yet, especially so in reference to one of the institutional options, namely, the adoption of public-private-people agreements. Indeed, in addition to establishing the ties needed to link public institutions with the business sector, some strong involvement of society as a whole is advised to foster the implementation of projects and expedite the solution of shared problems. At a local level, for instance, private stakeholder participation must be encouraged, with special attention to the latter's cultural closeness to the territory involved.

Originality/value - This research identifies some tools suitable for adoption in the cultural heritage field, which would serve as perfect examples of community involvement and commitment, and some useful case studies resulting from the Italian context.
\end{abstract}

Keywords Public-private-people partnership, P4, Public-private partnership, P3, Public cultural heritage, Management, Conservation, Valorization

Paper type Research paper

\section{Introduction}

In the light of the difficulties the governments typically face in conserving and managing their public cultural heritage, which often lingers in a condition of neglect, our objective is to identify a set of additional tools capable of providing adequate financial resources as well as skills by fostering a preliminary reflection on possible sector-specific models for the management of public-built cultural heritage that have not been well defined yet, and do so with special reference to one of the available institutional options, namely, the adoption of public-private agreements. More specifically, the paper refers to the Italian legal and institutional framework, as well as to case studies developed within the Italian context.

(C) Cristina Boniotti. Published by Emerald Publishing Limited. This article is published under the Creative Commons Attribution (CC BY 4.0) licence. Anyone may reproduce, distribute, translate and create derivative works of this article (for both commercial and non-commercial purposes), subject to full attribution to the original publication and authors. The full terms of this licence may be seen at http:// creativecommons.org/licences/by/4.0/legalcode

The author conveys her sincere gratitude to Prof. Stefano Della Torre of the Department of Architecture, Built Environment, and Construction Engineering of Politecnico di Milano for his supervising all current research activity. Special thanks, also, to Prof. Caroline Cheong (University of Central Florida, Department of History), Eduardo Rojas (University of Pennsylvania Stuart Weitzman School of Design), and Pietro Petraroia (Universitá Cattolica del Sacro Cuore and Cultura Valore S.R.L.) for their precious comments and suggestions.
Received 29 December 2020 Revised 9 February 2021 Accepted 21 March 2021

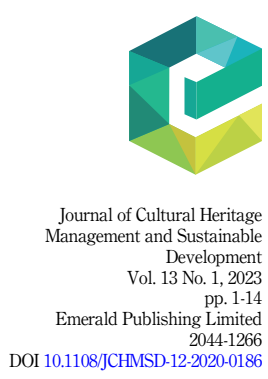


JCHMSD 13,1

These novel models contemplate the convergence of investments from different sectors into cultural heritage by means of negotiation dialogues and fostering the use of non-heritage funding originating from other domains such as the labor market, regional development and creative industries for the sake of achieving heritage and non-heritage-related goals (CHCfE Consortium, 2015, pp. 195-196). This alternative approach to cultural heritage enhancement implies that a tradeoff be pursued between different parties and the subsequent introduction of the concept of trading zone, which is, at once, a form of dialogue and cooperation, regardless of the divergencies existing between various sectors (Gustafsson, 2011; Balducci and Mäntysalo, 2013). This collaboration leads to resource collection for the purpose of conservation and valorization activities, thus boosting the exchange of good practices and abilities, and making new networks possible.

Although well-established opinions state that the conservation of cultural heritage as common goods basically pertains to the purview of the public sector, the participation of private resources may nonetheless pose an opportunity for the public administration to profit from novel funding channels. During a workshop organized by the Directorate-General for Research and Innovation of the European Commission, even the Horizon 2020 Expert Group on Cultural Heritage suggested that the public sector should revise its own approach to incentivize the private sector's becoming involved and investing in cultural heritage through new financial instruments such as tax breaks, differentiated value-added tax (VAT) brackets, well-designed grants, loan programs and public-private partnership (P3) schemes (European Commission - Directorate-General for Research and Innovation, 2015, p. 8).

Consistent with the models outlined previously, partnership is an organizational issue that implies some degree of cooperation between public and private entities, aimed at performing public duties and by which the resources and risks are shared on the basis of each partner's own field of expertise. The interest toward partnership schemes is consistent with the multiplicity of interactions they create and variety of operational instruments whereby they are implemented (concessions, sponsorships, etc.). As P3s have already been adopted in the past and in diverse contexts, as for instance infrastructure development, our research does not so much focus on innovating this alternative way of funding, but rather on describing and analyzing this emerging way of transacting between public and private organizations in the cultural heritage field, for it has not been widely adopted yet. In this context, heritage partnerships should be aimed at ensuring continuity and good planning in conservation activities to avoid becoming involved into fragmented and unvirtuous projects or even having to resort to divestment programs. Indeed, resources should be used not solely for spectacular restorations, but also continuous conservation and valorization after said plans have been accomplished (Della Torre, 1999).

As stated in the research report developed at the Getty Conservation Institute by Susan Macdonald and Caroline Cheong and entitled "The Role of Public-Private Partnership and the Third Sector in Conserving Heritage Buildings, Sites, and Historic Urban Areas," at the moment "There is a demand for further research on instruments and approaches that can be used to incentivize private and third sector involvement in the cultural heritage field and to encourage the public sector to work with private and third sector" (Macdonald and Cheong, 2014, p. 2).

\section{Different types of public-private agreements: P3 and P4}

The term "partnerships tools" refers to a wide range of management approaches and instruments, from procurement forms all the way to voluntary agreements, each of which aimed at different publicly pursued objectives.

Introduced as they have been in the past few decades, they may vary based on their fields of pertinence and the legal frameworks mandated and enforced by each given country. Sometimes, a relevant degree of inconsistency emerges within individual, national legislative frameworks - as is the case with Italy - which in turn warrants that terms and definitions be 
used and interpreted with special care. What matters here is that private sector organizations perform activities normally and naturally pertaining to the purview of public entities.

Indeed, $\mathrm{P} 3 \mathrm{~s}$ are a form of long-term cooperation between public and private entities aimed at absolving public duties such as the design, construction, management and maintenance stages of public works or services - in it, resources and risks are shared based on each party's skills and contribution (Cori and Paradisi, 2011, p. 41; World Bank Group - Public-PrivatePartnership Legal Resource Center, n.d.). As stated by the US American National Institute of Governmental Purchasing, the component of build may include renovation and/or rehabilitation: "A public-private partnership (P3) is a broad term used to describe public facility and infrastructure contracts that minimally include components of design and build (e.g. construction, renovation, rehabilitation) in a single contract. Components of financing, operations, maintenance, or management may be included within this single contract" (National Institute of Governmental Purchasing, 2016, p. 1). Thus, one important implication is that a given contract may entail an obligation of conservation upon restoration works completion.

Apart from the above, private actors can either be driven by:

(1) For-profit objectives, in which case, some return on investment must result. The transaction at issue can be termed a $P 3$, to wit, a collaboration between public and private entities aimed at eliciting some return in terms either of money or image (this is why, sponsorship initiatives are included).

The private entities at issue pertain to the business sector and may be either natural persons, legal persons with for-profit objectives (e.g. private universities), economic operators (e.g. construction companies) or financial institutions (e.g. investment banks, pension funds, insurance companies).

(2) Non-profit objectives, in which case a return on investment may be missing. The transaction at issue can be termed a public-private-people partnership (P4) and relates to instances of philanthropy in the presence of community support and with common citizens acting as project developers.

The private entities likely involved are of a civic-minded nature and may be either natural persons, legal persons with non-profit objectives (e.g. ecclesiastical entities), non-profit organizations, associations and various types of foundations (e.g. banking foundations). Concerning the latter, we should mention the Zagrebelsky decision, which sanctioned the nature of banking foundations as being private and was strongly supported by Lawyer Guzzetti, the past President of the Cariplo Foundation (Petraroia, 2018).

In the light of the ever-growing role played by regular citizens, this paper is aimed at lending a contribution to the definition of the tools suitable for this purpose and identifying some case studies developed in the Italian context.

\section{Definition and characteristics of public-private-people partnership}

To date, the P3 approach seems to be the offspring of neoclassical economic ideology, for private partners are considered as for-profit actors. Not surprisingly, most of its practical applications seem to have been designed and implemented as mere project financing tool transfers.

Some criticism has been leveled against this simplistic interpretation: Pietro Petraroia for instance notes a slew of private entities as being typically involved in the heritage game (Petraroia, 2013). Indeed, the connection between political institutions and business sectors as well as heavy community involvement encourages the implementation of projects and renders the solution of collective problems more effective (Dente et al., 2005, p. 42).

Adding to the P3 model the contribution suitable to be lent by the general population, a P4-based model will emerge, which provides for the involvement of the following groups of stakeholders: 
JCHMSD 13,1
(1) Public entities, i.e. the central government, local governments and public estate owners;

(2) Private entities, i.e. businesses, developers and private owners;

(3) People, i.e. common citizens, the non-profit sector and end-users.

The concept was conceived and studied by Wisa Majamaa in urban development, where P4 "Has created possibilities for engaging new pro-active and positive participation methods and solutions, not only for the early stages of urban development process (planning and design), but also for construction, operation and management of local economic and social infrastructure" (Majamaa, 2008, p. IV). The end-user-oriented method adopted in Majamaa's research to evaluate P4s encompasses not only value-for-money criteria, but also the categories of lifecycle approach, diversity and customer selection (Majamaa, 2008, p. 57).

In subsequent studies, the $\mathrm{P} 4$ has been analyzed as a form of community participation in the context of governance models and urban planning. More specifically, Raine Mäntysalo provided a critical review of the complexity of $\mathrm{P} 4$ in urban planning, suggesting deeming and handling it as a local trading zone (Mäntysalo, 2016; Puerari, 2016).

Thus, the involvement of social and economic actors plays an important role in governmental processes, and mainly so on a local scale. It discloses opportunities for implementing novel, proactive and positive ways of participating not only in the development of the project (as the investment and service provision-related decisions are typically made during the planning and design stages), but also for the executive and operational stages (Majamaa, 2008, pp. 34, 41, 55).

The whole community's involvement is strongly recommended even in urban preservation, and one of the prerequisites for sustainable operations warrants that each individual stakeholder put on the table all their competencies. As illustrated in Eduardo Rojas's theories, the situations characterized by some form of social concern incarnate the most advanced expression of urban heritage preservation as we know it (Rojas, 1999, p. 16).

The $\mathrm{P} 4$ model represents a highly refined form of integration by which people give birth to a quasi-organization, to wit something amounting to a half-formal, half-informal mechanism. As being a diverse and cohesive set of socio-economic actors cooperating with each other and public institutions, non-governmental actors are actively involved in the solving of shared problems. Citizens will thence become co-designers, co-producers and co-evaluators (Rizzo et al., 2014).

Moreover, we suggest that the $\mathrm{P} 4$ model be implemented in a context of mutual trust and accountability between stakeholders, namely, natural persons, groups and private sector entities.

Besides, we also ought to consider that our most relevant pieces of heritage, e.g. the Colosseum, are the subject of a degree of interest and scrutiny much closer compared to other types of "minor heritage." For their part, the latter cases warrant that more stubborn and locally centered resource-seeking initiatives be undertaken, for the conservation of such buildings implies a lesser degree of resonance. As a consequence, the co-opting of local actors becomes inevitable.

Partners roles, responsibilities and risks in public-private-people partnership Partnership agreements aimed at urban regeneration can also include individuals and nonprofit organizations such as foundations, trusts, culture clubs and visitors touring cities (Rojas, 2012, p. 147).

Recent Italian Legislative Decree July 03, 2017 n. 117, also known as "The Third Sector Statute," mandates that social cooperatives can be entrusted with managing cultural heritage 
provided they are equipped with the competencies set forth within the service contract. Its provisions confirm the current trend toward the fostering of non-profit entity involvement in these kinds of activities and services. More specifically, Article 55 provides for forms of co-design between public administrations and the third sector, and Article 71 provides the concession of publicly owned built cultural heritage needing restoration to third sector entities. The concession must aim at implementing a management project by ensuring adequate conservation and valorization (Petraroia and La Marca, 2017, p. 75).

The role of non-governmental organizations mainly consists in the identification of critical heritage buildings, provision of public advocacy, the rallying of support and initiation of redevelopment process. Besides, the third sector can also play a relevant role in providing an equity position, heritage conservation expertise and long-term supervision and assisting the public partner in marketing the project to potential private partners (Rypkema and Cheong, 2012, pp. 10-11).

Also, for a $\mathrm{P} 4$ initiative to be financially sustainable, some adequate risk assessment must be performed. As in the case of P3, the main categories to be included are risks consistent with politics, the environment, funding, design, development, restoration, unexpected events, enduser demand and/or revenue, operations and maintenance (Bellintani and Ciaramella, 2008, pp. 246-247; Baiardi, 2010, pp. 98-99; Rypkema and Cheong, 2012, p. 12; Martin, 2016, p. 201; Merola, 2017). In political decision-making, the risk can be controlled by getting all stakeholders to become involved (Majamaa, 2008, p. 53).

\section{Diversified tools of public-private-people partnership}

The interest toward partnership schemes is consistent with the multiplicity of interactions they beget and variety of operational instruments whereby they are implemented. The collaboration being developed also entails combining a range of competencies pertaining to various sectors. It is the expression of the need to integrate between different public bodies, private companies, non-profit entities, etc. It highlights the need to link to each other activities, functions, expertise and roles for the purpose of effectively handling a project's complexity (Codecasa, 2010, p. 175).

The research tries to identify the $\mathrm{P} 4$ tools suitable for adoption in the cultural heritage field, which would make perfect examples of community involvement and commitment.

P4 instruments are funding and management models aimed at conserving and valorizing instances of tangible and intangible cultural heritage based on citizen involvement such as civic crowdfunding, online petitions and contributions provided by foundations.

They are examples of self-organization, which have resulted in response to challenges posed by complex systems such as cities and society (Cameli, 2019, p. 33).

They are supported by philanthropy, volunteering and novel technologies. To this end, we should also stress that digital technologies and social media play critical roles and offer new opportunities (European Commission - Directorate-General for Research and Innovation, 2015, pp. 5, 9).

Civic crowdfunding is one of the most novel transaction forms involving citizens and public administrations, which is spreading, thanks to the internet. It differs from simple crowdfunding, in that it is aimed at financing public services and works. Albeit collective funding for public purposes is nothing new, its link with information technology marks an innovative aspect nonetheless. Civic crowdfunding differs from fundraising, also thanks to its internet-based functioning and huge number of backers. The online platform connects not only the financial institutions with the project, but also the different backers with each other, thus consolidating an otherwise highly dispersed financial capacity. It implies a direct community involvement in the planning, development and implementation of the public intervention. After the project has been accomplished, the management stage 
JCHMSD 13,1

6

is oftentimes supported by further non-profit associations. Civic crowdfunding is a spontaneous phenomenon, as such not contemplated within the classical model of public management. Besides, it allows to overcome the traditional top-down approach and develop decentralized forms of public government (Cameli, 2019).

Among the recently developed crowdfunding models suitable to be extended to the cultural heritage field is also real estate crowdfunding, an internet-based funding scheme launched in the USA in 2012, which has been widely adopted in recent years to help address the real estate market crisis (Morri and Ravetta, 2016). It certainly has for-profit objectives, but in light of its being an ever-more popular tool providing, also, an opportunity to choose the real estate product to invest in, we believe it ought to be analyzed in a cultural heritage perspective, too.

Two more tools suitable for consideration are social bonds and sustainability bonds. One of the relevant emerging issues is that public administrations are still to become familiar with these kinds of alternative funding instruments (Morena, 2020).

Even concession, which is a Design-Build-Finance-Operate-Maintain (DBFOM) tool (Martin, 2018, p. 3) mainly used in P3s, may be employed in operations aimed at involving the third sector. Indeed, in $\mathrm{P} 4 \mathrm{~s}$, the concession fee is generally either not contemplated or of a symbolic extent, as in the case of the Valore Paese - Cammini e Percorsi (Country Value Paths and Trails) project promoted by the Italian State Property Office and Ministry of Cultural Heritage.

The following is a graph with a list of the main P4 tools identified so far. Notice the growing degree in common citizen involvement (Figure 1).

\section{List of the main public-private-people partnership case studies identified}

The practice of third sector participation in restoration projects is far from being uncommon. However, and as is the case with P3 models, it may prove arduous to identify experiences where not only restoration works are implemented, but also the management of public-built cultural heritage.

We have come to identify the following most significant experiences as developed within the Italian context in the past few years. All the cases at issue are projects whereby not one individual, private actor alone, as is often the case with patronage initiatives, but whole groups of people have actively supported conservation and valorization activities (Tables $1-3$ ). Please note: to date, the author did not manage to identify all the private entities involved in the operations.

Special attention ought to be devoted to the experiences made by the Cariplo Banking Foundation. In recent years, Cariplo Foundation has been increasingly involved in the planning of Lombardy Region's cultural policies and initiatives. Due to the continuous decline in public funds available for culture, it has allocated to this very sector a slew of ever-increasing resources, while at the same time, gradually refining its strategies. It has tried to involve stakeholders, catalyze resources and strike, as well as strengthen alliances between public and private bodies. Aimed as it is at valorizing cultural heritage in terms of

Figure 1.

P4 tools, level and kind of people involvement

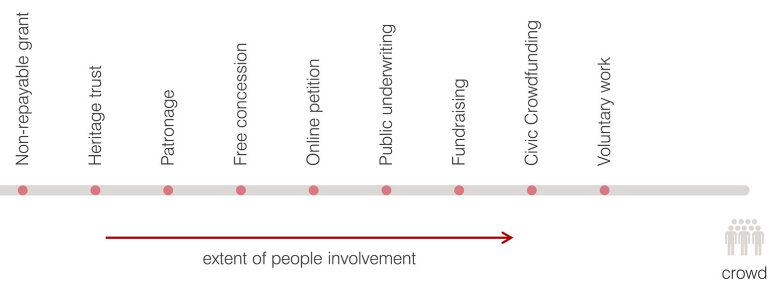




\begin{tabular}{|c|c|c|c|c|}
\hline Cultural heritage & Location & Private entity involved & Year & Public- \\
\hline $\begin{array}{l}\text { Archeological Site of } \\
\text { Herculaneum } \\
\text { Sito Archeologico di Ercolano }\end{array}$ & Ercolano & Packard Humanities Institute & 2001 & partnership \\
\hline $\begin{array}{l}\text { Cultural Districts Project } \\
\text { Progetto Distretti Culturali }\end{array}$ & $\begin{array}{l}\text { Lombardy } \\
\text { Region }\end{array}$ & $\begin{array}{l}\text { Cariplo Foundation } \\
\text { Non-repayable grant }\end{array}$ & 2005 & 7 \\
\hline $\begin{array}{l}\text { Cuccagna Farmhouse } \\
\text { Cascina Cuccagna }\end{array}$ & Milan & Cantiere Cuccagna Consortium & 2007 & \\
\hline $\begin{array}{l}\text { Collegiate San Giovanni } \\
\text { Battista } \\
\text { Collegiata San Giovanni } \\
\text { Battista }\end{array}$ & Morbegno & Isabel und Balz Baechi Foundation & 2012 & \\
\hline $\begin{array}{l}\text { Caimi Swimming Pool } \\
\text { Piscina Caimi }\end{array}$ & Milan & Pier Lombardo Foundation & 2014 & \\
\hline $\begin{array}{l}\text { San Luca Colonnade } \\
\text { Portico di San Luca }\end{array}$ & Bologna & $\begin{array}{l}\text { Committee for the restoration of the San Luca } \\
\text { Colonnade } \\
\text { Civic crowdfunding }\end{array}$ & 2014 & \\
\hline $\begin{array}{l}\text { The “+++ More Positive } \\
\text { Signs” Project } \\
\text { Progetto }+++ \text { Pì Segni } \\
\text { Positivi }\end{array}$ & Sondrio & $\begin{array}{l}\text { Cariplo Foundation } \\
\text { Non-repayable grant }\end{array}$ & 2015 & \\
\hline $\begin{array}{l}\text { The "Areactivation" Project } \\
\text { AttivAree Project (Oltrepò } \\
\text { Biodiverso + Valli Resilienti) }\end{array}$ & $\begin{array}{l}\text { Oltrepò Pavese + } \\
\text { Valle Trompia e } \\
\text { Sabbia }\end{array}$ & $\begin{array}{l}\text { Cariplo Foundation } \\
\text { Non-repayable grant }\end{array}$ & 2016 & \\
\hline $\begin{array}{l}\text { School of the } 40 \text { 's in via Santa } \\
\text { Croce } \\
\text { Scuola degli anni' } 40 \text { in via } \\
\text { Santa Croce }\end{array}$ & Milan & Emergency & 2017 & \\
\hline $\begin{array}{l}\text { Calchi Taeggi Boarding School } \\
\text { Collegio Calchi Taeggi }\end{array}$ & Milan & Non-profit organization & 2018 & \\
\hline $\begin{array}{l}\text { Castle of Pergine } \\
\text { Castello di Pergine }\end{array}$ & $\begin{array}{l}\text { Pergine } \\
\text { Valsugana }\end{array}$ & $\begin{array}{l}\text { CastelPergine Onlus Foundation } \\
\text { Public underwriting }\end{array}$ & 2018 & \\
\hline $\begin{array}{l}\text { House of Artists } \\
\text { Casa degli Artisti }\end{array}$ & Milan & $\begin{array}{l}\text { Temporary joint venture consisting of many } \\
\text { non-profit associations (ZONA K, That's } \\
\text { Contemporary, Spazio XPO', NIC) and a social } \\
\text { enterprise (Centro Itard Lombardia) }\end{array}$ & 2018 & \\
\hline $\begin{array}{l}\text { The Zamboni Villa } \\
\text { Villa Zamboni }\end{array}$ & $\begin{array}{l}\text { Valeggio sul } \\
\text { Mincio }\end{array}$ & $\begin{array}{l}\text { La Quarta Luna cultural association } \\
\text { Devolution agreement }\end{array}$ & 2020 & \\
\hline $\begin{array}{l}\text { Entire Village } \\
\text { Intero villaggio }\end{array}$ & $\begin{array}{l}\text { Cison di } \\
\text { Valmarino }\end{array}$ & Group of citizens & - & $\begin{array}{l}\text { Table 1. } \\
\text { P4 initiatives }\end{array}$ \\
\hline
\end{tabular}




\begin{tabular}{|c|c|c|c|c|}
\hline \multirow{3}{*}{$\begin{array}{l}\text { JCHMSD } \\
13,1\end{array}$} & \\
\hline & Cultural heritage & Location & Private entity involved & Year \\
\hline & $\begin{array}{l}\text { Gun Battery of Scarpa in S. Zeno in Monte } \\
\text { Batteria di Scarpa di S. Zeno in Monte }\end{array}$ & Verona & $\begin{array}{l}\text { The Comitato per il Verde } \\
\text { Association, Legambiente Verona, } \\
\text { Cariverona Foundation }\end{array}$ & 2011 \\
\hline \multirow[t]{2}{*}{8} & $\begin{array}{l}\text { Memorial Monument of Calatafimi } \\
\text { Sacrario di Calatafimi }\end{array}$ & $\begin{array}{l}\text { Calatafimi } \\
\text { Segesta }\end{array}$ & The Segesta nel Sogno Association & 2018 \\
\hline & $\begin{array}{l}\text { Country Value - Paths and Trails project } \\
\text { Progetto Valore Paese - Cammini e Percorsi } \\
\text { First call: } 43 \text { public buildings such as road } \\
\text { and railroad workers' houses, etc. (also not } \\
\text { listed) and located along cycle pedestrian } \\
\text { paths and historical-religious paths }\end{array}$ & $\begin{array}{l}\text { National } \\
\text { level }\end{array}$ & - & 2017 \\
\hline $\begin{array}{l}\text { Table } 2 \text {. } \\
\text { P4 initiatives } \\
\text { developed by the } \\
\text { Italian State Property } \\
\text { Office (Demanio } \\
\text { Agency) }\end{array}$ & $\begin{array}{l}\text { Country Value - Paths and Trails project } \\
\text { Progetto Valore Paese - Cammini e Percorsi } \\
\text { Second call: } 48 \text { public buildings such as } \\
\text { castles, villas, rural buildings, etc. (also not } \\
\text { listed) and located along pedestrian, cycling } \\
\text { and historical-religious paths }\end{array}$ & $\begin{array}{l}\text { National } \\
\text { level }\end{array}$ & - & 2018 \\
\hline
\end{tabular}

local development as part of a long-term vision, and doing so by means of investments in human capital, integration between the realms of manufacturing and culture, innovation in services and methodologies and sustainability, the Distretti Culturali (Cultural Districts) project can be considered a vivid example of culture-focused community welfare. The project consisted in the large-scale integration of different forms of cultural and economic activities and adopted a peculiar approach to increasing awareness and social participation in the heritage protection sector (Barbetta et al., 2013; Della Torre, 2015; Moioli, 2018). The working method that was developed during the Distretti Culturali project is currently being adopted by the foundation in other types of initiatives not necessarily pertaining to the cultural heritage field alone, as in the case of the intersectoral program AttivAree (“Areactivation"), which was developed most recently and aimed at reactivating Lombard remote inland areas devoid of essential services such as health, education and mobility in an attempt to reduce their isolation, increase their attractiveness and leverage community resources. Consistently with the "upstream perspective" defined in the final report of the European project Cultural Heritage Counts for Europe (CHCfE Consortium, 2015, pp. 195196), the activities developed within AttivAree were aimed at establishing interactions between different sectors while handling the economic, cultural, social and environmental domains as a whole (Osti and Jachia, 2020).

In addition to the above, the State Property Office is developing initiatives aimed at third sector actors. The Valore Paese - Cammini e Percorsi (Country Value - Paths and Trails) project is part of the broader Diamo Valore Italia ("Value for Italy") program promoted in cooperation with the Italian Ministry of Cultural Heritage and other institutional partners alike - among the agreements sanctioned is the one involving the National Institute for Microcredit, the purpose of which is to ensure reuse and fruition of public buildings located along, pedestrian, cycling and historical-religious heritage paths. The said operation is addressed to economic operators capable of employing public-private agreements in developing high-potential, tourism-oriented projects aimed at local areas and providing benefits for the community. A public consultation was initially launched and about 25,000 people lent their contributions in the form of ideas and suggestions (Agenzia del Demanio and 


\begin{tabular}{|c|c|c|c|c|}
\hline Cultural heritage & Location & Private entity involved & Year & $\begin{array}{r}\text { Public- } \\
\text { private-peonle }\end{array}$ \\
\hline $\begin{array}{l}\text { Church of San Pietro ad Oratorium } \\
\text { Chiesa di San Pietro ad Oratorium }\end{array}$ & Capestrano & - & 2016 & partnership \\
\hline $\begin{array}{l}\text { Church of San Barbaziano } \\
\text { Chiesa di San Barbaziano }\end{array}$ & Bologna & - & 2016 & \\
\hline $\begin{array}{l}\text { Castle of Canossa and Naborre Campanini } \\
\text { National Museum } \\
\text { Castello di Canossa e Museo Nazionale "Nal }\end{array}$ & $\begin{array}{l}\text { Canossa } \\
\text { re Campanini" }\end{array}$ & - & 2016 & 9 \\
\hline $\begin{array}{l}\text { The Giustiniani Villa } \\
\text { Villa Giustiniani }\end{array}$ & Bassano Romano & - & 2016 & \\
\hline $\begin{array}{l}\text { Charterhouse of Trisulti } \\
\text { Certosa di Trisulti }\end{array}$ & Collepardo & - & 2016 & \\
\hline $\begin{array}{l}\text { Abbey of Santa Maria di Vezzolano } \\
\text { Abbazia di Santa Maria di Vezzolano }\end{array}$ & Albugnano & - & 2016 & \\
\hline $\begin{array}{l}\text { The Castle } \\
\text { Il castello }\end{array}$ & Moncalieri & - & 2016 & \\
\hline $\begin{array}{l}\text { Abbey of Soffena } \\
\text { Abbazia di Soffena }\end{array}$ & $\begin{array}{l}\text { Castelfranco di } \\
\text { Sopra }\end{array}$ & - & 2016 & \\
\hline $\begin{array}{l}\text { Hermitage of San Leonardo al Lago } \\
\text { Eremo di San Leonardo al Lago }\end{array}$ & Monteriggioni & - & 2016 & \\
\hline $\begin{array}{l}\text { The Brandi Villa } \\
\text { Villa Brandi }\end{array}$ & Vignano & - & 2016 & Table 3. \\
\hline $\begin{array}{l}\text { The Colle del Cardinale Villa } \\
\text { Villa del Colle del Cardinale }\end{array}$ & Perugia & - & 2016 & $\begin{array}{r}\text { P4 initiatives } \\
\text { developed by the }\end{array}$ \\
\hline $\begin{array}{l}\text { The Bufalini Castle } \\
\text { Castello Bufalini }\end{array}$ & San Giustino & - & 2016 & $\begin{array}{l}\text { Cultural Heritage and } \\
\text { Activities and Tourism } \\
\text { within the project }\end{array}$ \\
\hline $\begin{array}{l}\text { The Villa del Bene } \\
\text { Villa del Bene }\end{array}$ & Dolcé & $\begin{array}{l}\text { Local Pro Loco (Local } \\
\text { promotion agency) }\end{array}$ & 2016 & $\begin{array}{l}\text { Cultura per il no profit } \\
\text { (Non-profit Culture) }\end{array}$ \\
\hline
\end{tabular}

Touring Club Italiano, n.d.). Most buildings have been assigned through two different types of contracts: concession/lease of valorization or free concession/lease, the latter of which can be framed within P4 initiatives in that free concessions have been granted for nine years to enterprises, cooperatives and associations mostly represented by people under the age of 40 . The first public tender was closed in 2017 with 47 offers (14 of which from abroad) and 33 participants (16 enterprises, eight cooperatives, and nine associations) (Agenzia del Demanio, n.d.).

In 2016, the Ministry of Cultural Heritage promoted the project Cultura per il no-profit (Non-profit Culture), aimed at conserving and managing public buildings not opened to visitors and adequately valorizing them by means of concessions. The call was opened to non-profit organizations with at least a five-year experience in cultural heritage support initiatives (Ministero per i Beni e le Attività Culturali e per il Turismo, 2016). For instance, the 16th-century Villa del Bene located in Dolcè (Province of Verona) is currently managed by the Regional Direction of Museums in conjunction with the local Pro Loco (Local promotion agency). It became a museum, study center, contemporary art gallery and venue for conferences and weddings (Villa Del Bene, n.d.).

Another initiative deserving attention is the acquisition of the Castle of Pergine (Province of Trento) by the CastelPergine Foundation, thanks to a public underwriting. Up to 
JCHMSD 13,1

November 23, 2020, 867 subscribers donated $€ 704,203$, while more than 50 associations and ten companies supported the operation (Fondazione CastelPergine Onlus, n.d.).

An example of civic crowdfunding is the restoration of the San Luca Colonnade in Bologna, which was promoted in 2014 by the Municipality of Bologna and a Committee and led to the collection of $€ 300,000$.

\section{0}

\section{Conclusions: not only financial benefits}

Thanks to P4 initiatives such as the Distretti Culturali (Cultural Districts) project and the AttivAree ("Areactivation") program, not only outstanding artifacts, but also some instances of "minor heritage" recognized as such by local communities underwent conservation and were made accessible to citizens. Other than P3 operations, the latter programs consisted in the large-scale integration of different forms of cultural and economic activities and, what is more, proved to be a viable means of increasing awareness and social participation in the heritage protection sector. Indeed, the projects' main objective was to not solely plan a strategy of cultural heritage valorization based on high-end interventions, innovative actions and a long-term perspective, but also to mutually integrate the cultural supply chain and the local economy and implement an innovative approach to activity management and development to be defined in cooperation with all local stakeholders.

The strategy described herein is in line with the Faro Convention, which highlights the need to involve society as a whole in defining and managing cultural heritage, recognizes the collective nature of said commitment and fosters competency synergies between public and private actors. Article 2 underscores the relevance of the concept of "heritage community" as consisting "of people who value specific aspects of cultural heritage which they wish, within the framework of public action, to sustain and transmit to future generations." Article 11 envisions "the possible joint action by public authorities, experts, owners, investors, businesses, non-governmental organizations and civil society", the development of "innovative ways for public authorities to co-operate with other actors," and encouraging "non-governmental organizations concerned with heritage conservation to act in the public interest" (Council of Europe, 2005).

Even the Historic Urban Landscape (HUL) approach as developed by the UNESCO is promoting the application of a range of traditional as well as novel tools to be adopted at a local level by involving stakeholders through participatory planning and consultations. These may include civic engagement, knowledge, planning and financial tools and regulatory systems (UNESCO, 2011; UNESCO, 2013). The HUL approach calls for all levels of governance (be it local, regional or national/federal) to define and develop conservation policies based on public-private stakeholder cooperation (UNESCO, 2011). Not surprisingly, quite a few practical guides and reports testify to an ever-increasing number of instances of implementation of this approach (UNESCO, 2016; UNESCO, 2019).

The European PPP Expertise Centre stressed that public authorities usually embark on projects the investment into which makes good economic sense. Nevertheless, and compared to conventionally procured projects, partnerships also imply a set of non-financial benefits to end users and, in broader terms, society as a whole. Some benefits may be valued in monetary terms, whereas others may be quantified yet not valued in monetary terms, and others still can neither be quantified nor valued but only identified. They are typically associated with three possible key mechanisms: accelerated delivery, enhancement delivery and wider social impacts (European PPP Expertise Centre, 2011).

Also influenced by some urban planning studies developed over the 1960s (Jacobs, 1961; Davidoff, 1965), the current public management is acknowledging some limits in the traditional models focused, as they are, solely on economic outcomes such as the gross domestic product (GDP) impact and instead considering novel holistic approaches including 
qualitative aspects, such as the administrative process democratization, social equity, community involvement and individual well-being (Park and Joaquin 2012; Cameli, 2019).

Despite reward assessments being a difficult task, "One of the key benefits of PPPs is that it adopts a life-cycle approach aimed at preserving the function and usability of an asset for the contract period which generally corresponds to its useful economic life" (European PPP Expertise Centre, 2011, p. 25).

In this respect, further lines of research will likely focus on both the financial and nonfinancial benefits to these operations, with special regard to the data resulting from actual case studies and practical experiences. Besides, more research is warranted as to further P4 types, to best assess the potential and limitations inherent to the various partnership tools either available or under development.

Even if some positions envision partnerships as a form of commodification, we ought to stress that these initiatives call for the partners involved to ensure not only long-term protection of the historical buildings to be restored, but also some management skills consistent with long-time conservation and valorization.

All public and private parties need to boast competences consistent with such partnership tools and be aware that the resources shall be allocated not solely for restoration works, but also to ensure a condition of ongoing care for the asset at issue. The implementation of the interventions must be carefully monitored by the public entity in charge throughout all stages of the process until the completion of all operations.

\section{References}

Agenzia del Demanio and Touring Club Italiano (n.d.), "Consultazione Pubblica Progetto Cammini e Percorsi. Sintesi dei risultati", available at: https://www.agenziademanio.it/export/sites/ demanio/download/schedeapprofondimento/REPORT-SHORT_CAMMINI-E-PERCORSI-da-5.0. pdf (accessed 29 December 2020).

Agenzia del Demanio (n.d.), "Valore paese - cammini e percorsi", available at: https://www. agenziademanio.it/opencms/it/progetti/camminipercorsi/ (accessed 29 December 2020).

Baiardi, L. (2010), "La valorizzazione e il concetto di redditività degli immobili", Tronconi, O. and Baiardi, L. (Eds), Valutazione, valorizzazione e sviluppo immobiliare, Maggioli Editore, Santarcangelo di Romagna, pp. 61-101.

Balducci, A. and Mäntysalo, R. (Eds) (2013), Urban Planning as a Trading Zone, Springer, Dordrecht.

Barbetta, G.P., Cammelli, M. and Della Torre, S. (Eds) (2013), Distretti Culturali: Dalla Teoria Alla Pratica, il Mulino, Bologna.

Bellintani, S. and Ciaramella, A. (2008), L'audit immobiliare. Manuale per l'analisi delle caratteristiche degli edifici e dei patrimoni immobiliari, Il Sole 24 ore, Milano.

Cameli, S.A. (2019), "Il civic crowdfunding e il futuro della pubblica amministrazione", Rivista Italiana di Public Management, Vol. 2 No. 1, pp. 19-45.

CHCfE Consortium (2015), "Cultural heritage counts for Europe”, full report, available at: http://blogs. encatc.org/culturalheritagecountsforeurope/outcomes/ (accessed 29 December 2020).

Codecasa, G. (2010), "Ripensare i governi urbani. Spunti per un'agenda di ricerca”, in Codecasa, G. (Ed.), Governare il partenariato pubblico e privato nei progetti urbani, Maggioli Editore, Santarcangelo di Romagna, pp. 151-198.

Cori, R. and Paradisi, I. (2011), "Una ipotesi di lavoro: l'applicazione ai servizi del sistema dei beni culturali del Project Financing”, Leon, A. and Verdinelli De Cesare, P. (Eds), Qualità dei bandi per l'acquisto di servizi nel sistema dei beni culturali. I servizi del sistema dei beni culturali: come interpretarli, combinarli, innovarli, qualificarli, Vol. 2, pp. 41-52, available at: https://www. promopa.it/images/ricerca/i-servizi-del-sistema-dei-beni-culturali_2.pdf (accessed 29 December 2020). 
JCHMSD 13,1

Council of Europe (2005), "Framework convention on the value of cultural heritage for society", available at: https://www.coe.int/en/web/conventions/full-list/-/conventions/rms/ 0900001680083746 (accessed 29 December 2020).

Davidoff, P. (1965), "Advocacy and pluralism in planning", Journal of the American Institute of Planners, Vol. 31 No. 4, pp. 331-338, doi: 10.1080/01944366508978187.

Della Torre, S. (1999), “"Manutenzione” o "Conservazione”? La sfida del passaggio dall'equilibrio al divenire", in Biscontin, G. and Driussi, G. (Eds), Ripensare alla manutenzione: ricerche, progettazione, materiali, tecniche per la cura del costruito, Atti del XV Convegno Scienza e Beni Culturali, Arcadia Ricerche, Marghera-Venezia, Bressanone, pp. 71-80.

Della Torre, S. (2015), "Shaping tools for built heritage conservation: from architectural design to program and management. Learning from "Distretti culturali"', Van Balen, K. and Vandesande, A. (Eds), Community Involvement in Heritage, Garant, Antwerp and Apeldoorn, pp. 93-101.

Dente, B., Bobbio, L. and Spada, A. (2005), “Government or governance of urban innovation?”, The Planning Review, Vol. 41 No. 162, pp. 41-52, doi: 10.1080/02513625.2005.10556931.

European Commission - Directorate-General for Research and Innovation (2015), "Getting cultural heritage to work for Europe. Report of the horizon 2020 expert group on cultural heritage", available at: https://ec.europa.eu/programmes/horizon2020/en/news/getting-cultural-heritagework-europe (accessed 29 December 2020).

European PPP Expertise Centre (2011), "The non-financial benefits of PPPs. An overview of concepts and methodology", available at: https://www.eib.org/en/publications/epec-the-non-financialbenefits-of-ppps (accessed 29 December 2020).

Fondazione CastelPergine Onlus (n.d.), Available at: https://www.fondazionecastelpergine.eu/ (accessed 29 December 2020).

Gustafsson, C. (2011), The Halland Model. A Trading Zone for Building Conservation in Concert with Labour Market Policy and the Construction Industry, Aiming at Regional Sustainable Development, University of Gothenburg, Gothenburg.

Jacobs, J. (1961), The Death and Life of Great American Cities, Random House, New York.

Macdonald, S. and Cheong, C. (2014), The Role of Public-Private Partnerships and the Third Sector in Conserving Heritage Buildings, Sites, and Historic Urban Areas, The Getty Conservation Institute, Los Angeles.

Majamaa, W. (2008), The 4th P - People - in Urban Development Based on Public-Private-People Partnership, Helsinki University of Technology, Espoo.

Mäntysalo, R. (2016), "From public-private-people partnerships to trading zones in urban planning", in Concilio, G. and Rizzo, F. (Eds), Human Smart Cities. Rethinking the Interplay between Design and Planning, Springer, Cham, pp. 141-157, doi: 10.1007/978-3-319-33024-2_8.

Martin, L. (2016), "Making sense of public-private partnerships (P3s)", Journal of Public Procurement, Vol. 16 No. 2, pp. 191-207, doi: 10.1108/JOPP-16-02-2016-B002.

Martin, L. (2018), "Public-private Partnerships (P3s): what local government managers need to know. A policy issue white paper for ICMA, International City/County management association", International City/County Management Association, Washington, DC, available at: https:/icma. org/documents/public-private-partnerships-p3s-what-local-government-managers-need-know (accessed 29 December 2020).

Merola, F. (2017), Investimenti in Asset Reali: Dall'immobiliare Alle Infrastrutture, lesson held at Luiss Business School, EREF Executive Program in Real Estate Finance, 10 November 2017, mimeo, Roma.

Ministero per i Beni e le Attività Culturali e per il Turismo (2016), "Cultura per il no profit. Pubblicato il bando per la concessione in uso a privati di beni immobili del demanio culturale dello stato non aperti alla fruizione pubblica o non adeguatamente valorizzati”, available at: https://www. beniculturali.it/comunicato/cultura-per-il-no-profitpubblicato-il-bando-per-la-concessione-in-uso- 
a-privati-di-beni-immobili-del-demanio-culturale-dello-stato-non-aperti-alla-fruizione-pubblica-onon-adeguatamente-valorizzati (accessed 29 December 2020).

Moioli, R. (2018), “The spinning mill in Sulbiate: a place for changes", Van Balen, K. and Vandesande, A. (Eds), Innovative Built Heritage Models, Reflections on Cultural Heritage Theories and Practice (3), Taylor \& Francis Group, London, pp. 151-159.

Morena, M. (2020), Strumenti finanziari alternativi per la pubblica amministrazione. Civic Crowdfunding, Social Bond, Green Bond e Sustainability Bond, XIII Edizione OPPAL Osservatorio Permanente sulla Pubblica Amministrazione Locale, Politecnico di Milano, online event, 26 November 2020, Milano.

Morri, G. and Ravetta, M. (2016), "Real estate crowdfunding. A financial innovation for direct property investment”, Territorio Italia, No. 2, pp. 9-24, available at: https:/www.agenziaentrate.gov.it/ portale/documents/20143/325335/Real+Estate+Crowdfunding+innovazione+inglese Morri+INGLESE_2016.pdf/0cd9cc9b-edbc-11fd-3dcb-d44989e4a346 (accessed 29 December 2020), doi: 10.14609/Ti_2_16_1e.

National Institute of Governmental Purchasing (2016), "Public procurement practice. Public-private partnership (P3): facilities and infrastructure", Guidance Issued by the National Institute of Governmental Purchasing to State and Local Government Procurement Officials, available at: https://www.nigp.org/resource/global-best-practices/Public-Private\%20Partnership \%20P3\% 20Facilities\%20and\%20Infrastructure\%20Best\%20Practice.pdf (accessed 29 December 2020).

Osti, G. and Jachia, E. (2020), AttivAree. Un disegno di Rinascita Delle Aree Interne, il Mulino, Bologna.

Park, S.M. and Joaquin, M.E. (2012), "Of alternating waves and shifting shores: the configuration of reform values in the US federal bureaucracy", International Review of Administrative Sciences, Vol. 78 No. 3, pp. 514-536, doi: 10.1177/0020852312442659.

Petraroia, P. (2013), "Non esiste un solo "Pubblico" e un solo "Privato"”, 15 November 2013, Il Giornale delle Fondazioni, available at: http://www.ilgiornaledellefondazioni.com/content/non-esiste-unsolo- $\%$ C2 $\%$ ABpubblico $\%$ C2 $\%$ BB-e-un-solo- $\%$ C2\% ABprivato $\% \mathrm{C} 2 \% \mathrm{BB}$ (accessed, 29 December 2020).

Petraroia, P. (2018), "Partenariato tra pubblico e privato nella tutela e nella valorizzazione dei beni culturali", Bellini, A., Petraroia, P. and Robbiati Bianchi, A. (Eds), Individuazione e tutela dei beni culturali Problemi di etica, diritto ed economia, Istituto Lombardo - Accademia di Scienze e Lettere, pp. 23-39, available at: http://www.ilasl.org/index.php/Incontri/article/view/332 (accessed 29 December 2020).

Petraroia, P. and La Marca, D. (2017), "Per un'imprenditoria qualificata nella gestione di beni e servizi culturali", in XIII Rapporto Annuale Federculture. Impresa Cultura. Gestione Innovazione Sostenibilità, Gangemi Editore, Roma, pp. 67-79.

Puerari, E. (2016), "Urban public services innovation. Exploring the $3 \mathrm{P}$ and $4 \mathrm{P}$ models", $\mathrm{PhD}$ thesis, supervisor Concilio, G., Politecnico di Milano, Milano.

Rizzo, F., Concilio, G. and Molinari, F. (2014), "My Neighbourhood: un progetto di vicinato intelligente", Forum Pubblica Amministrazione, 3 September 2014, available at: https://www. forumpa.it/open-government/partecipazione-trasparenza/my-neighbourhood-un-progetto-divicinato-intelligente/ (accessed 29 December 2020).

Rojas, E. (1999), Old Cities, New Assets: Preserving Latin America's Urban Heritage, Inter-American Development Bank, Washington, DC.

Rojas, E. (2012), "Governance in historic city core regeneration projects", Licciardi, G. and Amirtahmasebi, R. (Eds), The Economics of Uniqueness. Investing in Historic City Cores and Cultural Heritage Assets for Sustainable Development, The World Bank, Washington, DC, pp. 143-181.

Rypkema, D. and Cheong, C. (2012), Public-Private Partnerships and Heritage: A Practitioner's Guide, Heritage Strategies International, Washington.

UNESCO (2011), "Recommendation on the Historic Urban Landscape”, Paris, 10 November 2011, available at: http://portal.unesco.org/en/ev.php-URL_ID $=48857 \& U R L \_D O=D O \_$ TOPIC\&URL_SECTION=201.html (accessed 7 February 2021).

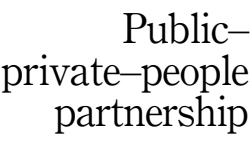


JCHMSD

13,1

14
UNESCO (2013), "New life for historic cities. The historic urban landscape approach explained", United Nations Educational, Scientific and Cultural Organization (UNESCO), Paris, available at: https://whc.unesco.org/en/activities/727/ (accessed 7 February 2021).

UNESCO (2016), "The HUL guidebook. Managing heritage in dynamic and constantly changing urban environments. a practical guide to UNESCO's recommendation on the Historic Urban Landscape", available at: http:/historicurbanlandscape.com/themes/196/userfiles/download/ 2016/6/7/wirey5prpznidqx.pdf (accessed 7 February 2021).

UNESCO (2019), "The UNESCO recommendation on the historic urban landscape. Report of the second consultation on its implementation by member states", UNESCO World Heritage Centre, Paris, available at: https://whc.unesco.org/en/hul/ (accessed 7 February 2021).

Villa Del Bene (n.d.), Available at: https://www.villadelbene.com/ (accessed 29 December 2020).

World Bank Group - Public-Private-Partnership Legal Resource Center (n.d.), "About public-private partnerships", available at: https://ppp.worldbank.org/public-private-partnership/about-publicprivate-partnerships (accessed 29 December 2020).

\section{Corresponding author}

Cristina Boniotti can be contacted at: cristina.boniotti@polimi.it

For instructions on how to order reprints of this article, please visit our website: 